\title{
Norræn samstarfsáætlun á sviði orkumála 2018-2021
}

(11) Norræna ráðherranefndin 
Norræn samstarfsáætlun á sviði orkumála 2018-2021

ANP 2017:771

ISBN 978-92-893-5211-6 (PRINT)

ISBN 978-92-893-5212-3 (PDF)

ISBN 978-92-893-5213-O (EPUB)

http://dx.doi.org/10.6027/ANP2017-771

(c) Norræna ráðherranefndin 2017

Umbrot: Gitte Wejnold

Kápumynd: Unsplash.com

Prentun: Rosendahls

Printed in Denmark

\section{Norrænt samstarf}

Norræna samstarfið er eitt umfangsmesta svæðasamstarf í heiminum.

Samstarfið byggir á landfræðilegri legu landanna, sameiginlegri sögu peirra og menningu. Að samstarfinu koma Danmörk, Finnland, Ísland, Noregur og Svípjóð auk Álandseyja, Færeyja og Grænlands.

Norræna samstarfið er pólitískt, efnahagslegt og menningarlegt og skiptir miklu í evrópsku og alpjóðlegu samstarfi. Löndin vinna saman að pví að marka Norðurlöndum stöðu í öflugri Evrópu.

Með norrænu samstarfi er unnið að pví að gæta hagsmuna svæðisins og efla norræn gildi í hnattrænum heimi. Sameiginleg gildi landanna styrkja stöðu Norðurlanda og skipa peim meðal peirra svæða í heiminum par sem nýsköpun og samkeppnishæfni er mest.

\section{Norræna ráŏherranefndin}

Nordens Hus

Ved Stranden 18

DK-1061 Copenhagen $\mathrm{K}$

www.norden.org

Sækja útgefið efni: www.norden.org/nordpub 


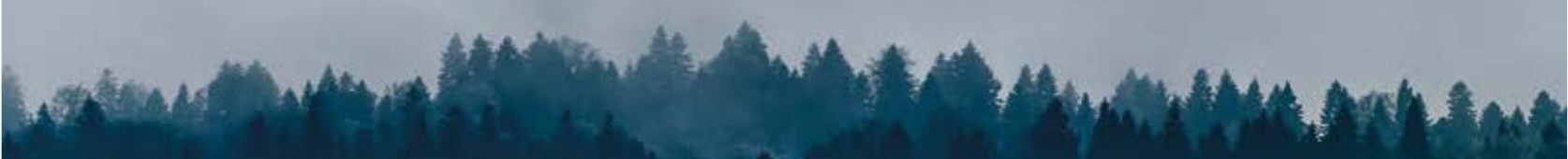

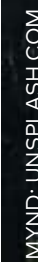

1 



\section{EFNISYFIRLIT}

Formáli

$\begin{array}{ll}\text { Inngangsorð } & 8\end{array}$

$\begin{array}{ll}\text { Markmiðð og forgangsröðun } & 12\end{array}$

Norrænn raforkumarkaður 14

$\begin{array}{ll}\text { Endurnýjanlegir orkugjafar } & 18\end{array}$

$\begin{array}{ll}\text { Að auka orkunýtni } & 20\end{array}$

Upplýsingaskipti og samráo um stefnu norrænu landanna í orkumálum 22

$\begin{array}{lr}\text { Orkurannsóknir } & 23\end{array}$

Norðurlönd í Evrópu (ESB/EES) og annað̃ alpjóðlegt samstarf 25

$\begin{array}{ll}\text { Pverlæg bemu } & 28\end{array}$

Orkutengdir fletir á samgöngumálum $\quad 28$

Norrænt orkumálasamstarf á Álandseyjum, í Færeyjum og á Grænlandi 30

Samhengi við pverlæg stefnumótunarskjöl 30

Viðauki A

Skipulag sviðsins $\quad 32$

Viðauki B

Stefnumótandi úttekt á sviði orkumála 33

Viðauki C

Stefnumarkandi umboð fyrir Norrænar orkurannsóknir 


\section{FORMÁLI}

Norðurlöndin eiga með sér öflugt og lifandi samstarf á sviði orkumála. Í norrænni samstarfsáætlun um orkumál fyrir tímabilið 2018-2021 er fjallað um samstarfssvið Norðurlanda í orkumálum. Norrænn raforkumarkaður, endurnýjanleg orka, orkunýtni og orkurannsóknir verða mikilvæg áherslusvið í norrænu orkumálasamstarfi hér eftir sem hingað til.

Einn liður í undirbúningi að nýrri norrænni samstarfsáætlun á sviði orkumála hefur falist í svonefndri stefnumótandi úttekt á norrænu orkumálasamstarfi. Pað var Jorma Ollila sem rýndi í orkumálasamstarfið og lagði fram mikilvægar tillögur. Við kunnum Ollila pakkir fyrir vel unnið verk. Tillögur hans hafa reynst dýrmætt framlag til kortlagningar á næstu skrefum í orkumálasamstarfinu.

Norrænt samstarf á sviði orkumála mun áfram taka mið af peirri staðreynd að Evrópusambandið hefur sett aukinn kraft í stefnumótun og próun regluverks í starfi sem miðar að pví að móta orkubandalag ESB. Ö॥ norrænu löndin verða fyrir áhrifum af starfi ESB með ólíkum hætti og geta átt ólíkra hagsmuna að gæta á sviði orkumála, en einnig getur pað komið sér vel fyrir löndin að hafa í sameiningu áhrif á samninga- og framkvæmdaferli á ESB/EES-svæðinu. Áframhaldandi farsælt samstarf um Evrópumál er forsenda farsæls norræns samstarfs um orkumál. Markmiðið með hinni nýju samstarfsáætlun er að efla samstarf um málefni ESB/EES á sviði orkumála.

Mikilvægt er að við nýtum öll norræn tengslanet og samstarfsstofnanir og aukum pannig möguleika okkar til áhrifa á sviðum par sem sameiginlegir hagsmunir eru til staðar. Við verðum að læra hvert af öðru á sviðum par sem samlegðaráhrif eru fyrir hendi i framkvæmd á 
stefnum og regluverki Evrópusambandsins. Við búum að langri og farsælli hefð fyrir norrænu samstarfi á sviði raforku. Samstarfið fer fram á ólíkum stigum og milli mismunandi aðila, og í auknum mæli innan evrópsks ramma. Í pessari samstarfsáætlun er framtíðarsýninni um farsælt norrænt samstarf á sviði raforku enn haldið á lofti.

Í áætluninni er ennfremur lögð aukin áhersla á svæðisbundin upplýsingaskipti á sviði orkumála fram að árinu 2030. Mikilvægt er að grannar upplýsi hverjir aðra um pýðingarmikil próunarmynstur og ákvarðanir í orkumálum norrænu landanna.

Norrænu löndin munu áfram eiga gott samstarf um rannsóknir, próun og tækni á sviði orkumála. Saman munum við halda áfram að sýna Evrópu og heiminum öllum snjallar lausnir við áskorunum framtíðarinnar á fjölmörgum sviðum er varða endurnýjanlega orku, aukna orkunýtni, samgöngumál og hreyfanleika raforku. Við verðum eftir sem áður að greiða fyrir gagnlegum verkefnum á Álandseyjum, í Færeyjum og á Grænlandi.

Við teljum að Evrópa og heimurinn hafi pörf fyrir Norðurlönd sem vinni saman að markmiðum um öruggan orkubúskap, skilvirkan raforkumarkað, sjálfbæran hagvöxt og velmegun fyrir íbúana.

Terje Søviknes olíu- og orkumálarádherra, fyrir hönd formennsku Noregs i Norrænu rádherranefndinni 2017 


\section{Inngangsorð}

Norðurlöndin eiga með sér öflugt og lifandi samstarf á sviði orkumála. Gott dæmi er sameiginlegur raforkumarkaður landanna, sem byggir á metnaðarfullri framtíðarsýn um sjálfbært orkukerfi á Norðurlöndum.

Í tengslum við almennt umbótaferli í norrænu samstarfi var unnin stefnumótandi úttekt á norrænu orkumálasamstarfi og greining á sóknarfærum í pví samstarfi til næstu 5-10 ára. Hin stefnumótandi úttekt var unnin af Jorma Ollila, fyrrum forstjóra Nokia, og hefur hún komið að miklu gagni sem innblástur við gerð pessarar samstarfsáætlunar.

Áætlunin fyrir tímabilið 2018-2021 byggir á niðurstöðum úttektarinnar og samstarfsins fram til pessa.

Tillaga Ollila um að skilgreina skýra sýn fyrir orkumálasamstarfið hefur verið tekin til greina og nýtist hún sem almennur rammi um markmið í áframhaldandi samstarfi um orkumál á Norðurlöndum.

Löndin ræða sífellt fleiri viðfangsefni á sviði orkumála sín á milli. Prátt fyrir ólíka orkugjafa og ólíkt skipulag orkumála í löndunum er greinilegur áhugi fyrir pví á Norðurlöndum að hafa áhrif á pá ferla sem eiga sér stað, nú pegar stefnan í orkumálum fær aukna evrópska og hnattræna skírskotun. Norrænu löndin standa sterkar að vígi pegar pau geta sýnt samstöðu í einstökum málum. Með pví að tryggja stöðugt flæði upplýsinga um afstöðu landanna og lausnir sem pau leggja til á viðfangsefnum á sviði orkumála á landsbundnum, svæðisbundnum, evrópskum og alpjóðlegum vettvangi, má auka áhrif landanna enn frekar.

Ferlar og aðgerðir ESB á sviði orkumála hafa áhrif á Norðurlönd. Petta á við um öll norrænu löndin, ýmist á vettvangi ESB eða EES. Talið er að framtíðarsýnin um evrópskt orkubandalag og tillögur par að lútandi, sem nú eru í ákvörðunarferli og á framkvæmdastigi, muni skipta miklu við mótun framtíðarstefnu landanna í orkumálum.

Norrænt orkumálasamstarf kemur einnig að pverlægum verkefnum og áætlunum, bæði á norrænum og alpjóðlegum vettvangi. Gott dæmi um norrænt verkefni á alpjóðlegum vettvangi er sameiginlegt gestgjafahlutverk Norðurlanda og framkvæmdastjórnar Evrópusambandsins á alpjóðlegum fundum orkumálaráðherra undir yfirskriftinni Clean Energy Ministerial 


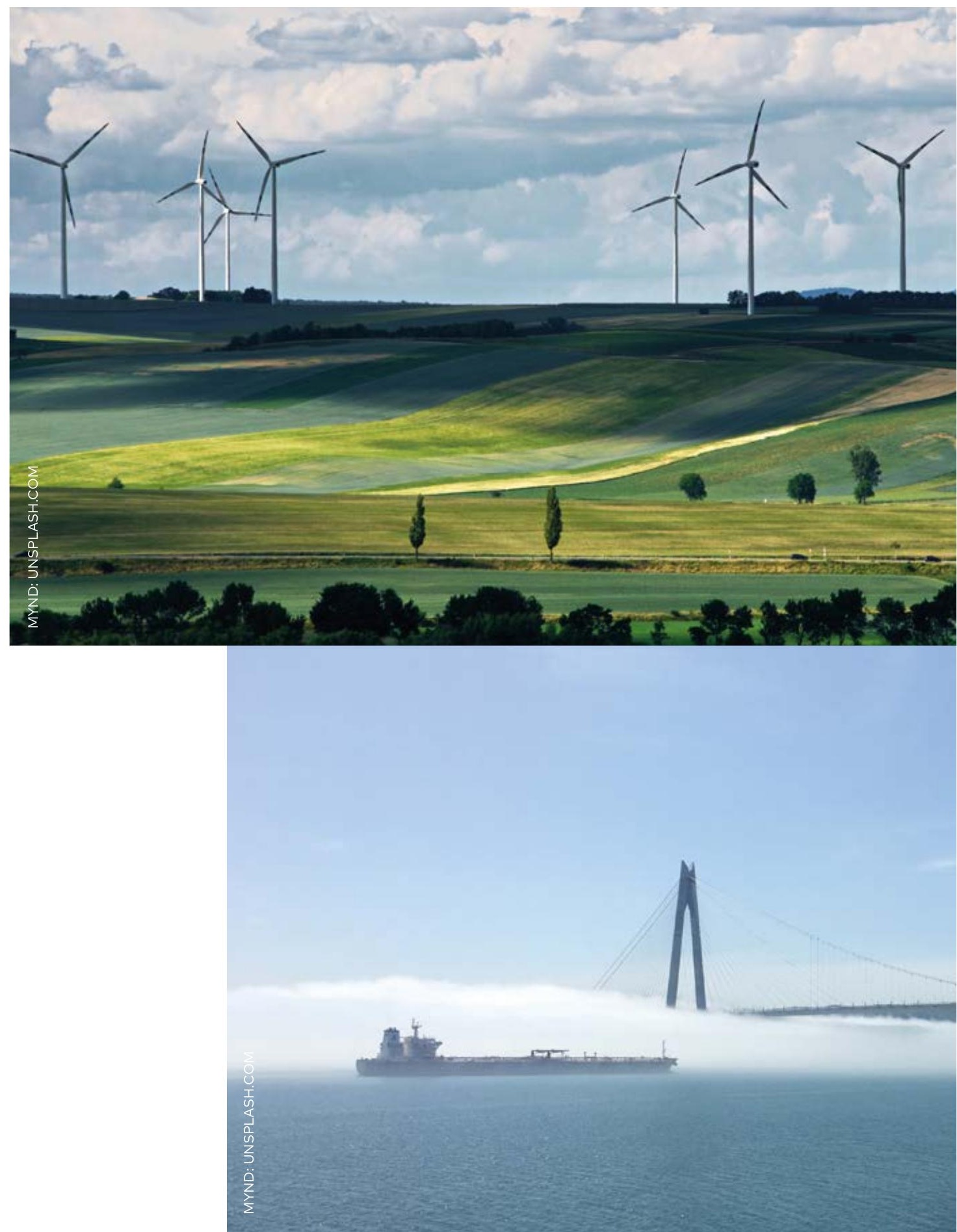


9 og Mission Innovation 3, sem haldnir verða á vordögum 2018.

Pegar kemur að aðgerðum á sviði orkumála leggur norrænt orkusamstarf áherslu á svið sem hafa skýrt pólitískt vægi og norrænt notagildi. Pað getur til dæmis átt við áframhaldandi próun norræns raforkumarkaðar. Samfara pví að norrænu orkukerfin verða æ samstilltari fjölgar viðfangsefnunum, m.a. vegna pess að kerfi landanna eða lagasetning er mismunandi. Slík mál ætti að ræða jafnóðum og taka á peim á vettvangi norræns samstarfs. Sama á við um sampættingu norræns orkumálasamstarfs við hið evrópska.

Annað sem einkennir Norðurlönd og norrænt orkumálasamstarf er að sérstakar áskoranir kunna að vera til staðar á Álandseyjum, í Færeyjum og á Grænlandi. Sama gildir um afskekkt svæði sem eru ekki tengd við hinn sameiginlega raforkumarkað. Í samstarfsáætluninni fyrir tímabilið 2018-2021 er sérstök áhersla lögð á að próa markvissar lausnir fyrir orkumálasamstarfið í góðu samstarfsneti orkumálayfirvalda og annarra viðeigandi aðila.
Á vettvangi Norrænna orkurannsókna (NEF) fer fram samvinna um tæknipróun í hagnýtum rannsókna- og próunarverkefnum sem getur skapað norrænt notagildi og virðisauka fyrir löndin. Norrænu löndin hafa ólíkar styrkleikastöður á sviðum nýsköpunar og próunar. Pá hafa Norrænar orkurannsóknir (NEF), ásamt Alpjóðaorkumálastofnuninni (IEA), tekið saman skýrsluna Nordic Energy Technology Perspectives (NETP) og greint á grundvelli hennar hvernig samspil mismunandi orkulausna getur stuðlað að pví að norrænu löndin nái markmiðum sínum í orku- og loftslagsmálum fyrir árið 2050.

\footnotetext{
${ }^{1}$ Clean Energy Ministerial (CEM) er albjóðlegur vettvangur forystufólks til að kynna stefnur og áætlanir sem efla hreinar orkulausnir, deila reynslu og bestu starfsháttum og stuðla að umskiptum til hnattræns hagkerfis hreinnar orku.

Mission Innovation (MI) er hnattrænt framtaksverkefni sem hefur pað að markmiði að greiða verulega fyrir nýsköpun á sviði hnattrænnar hreinorku. Hluti framtaksverkefnisins er fólginn í bví að pátttökulöndin hafa skuldbundið sig til pess að tvöfalda fjárfestingu hins opinbera í rannsóknum og próun á sviði hreinnar orku á fimm ára tímabili (fram til 2020), og hvetja jafnframt einkageirann til aukinna fjárfestinga í hreinum orkulausnum.
} 


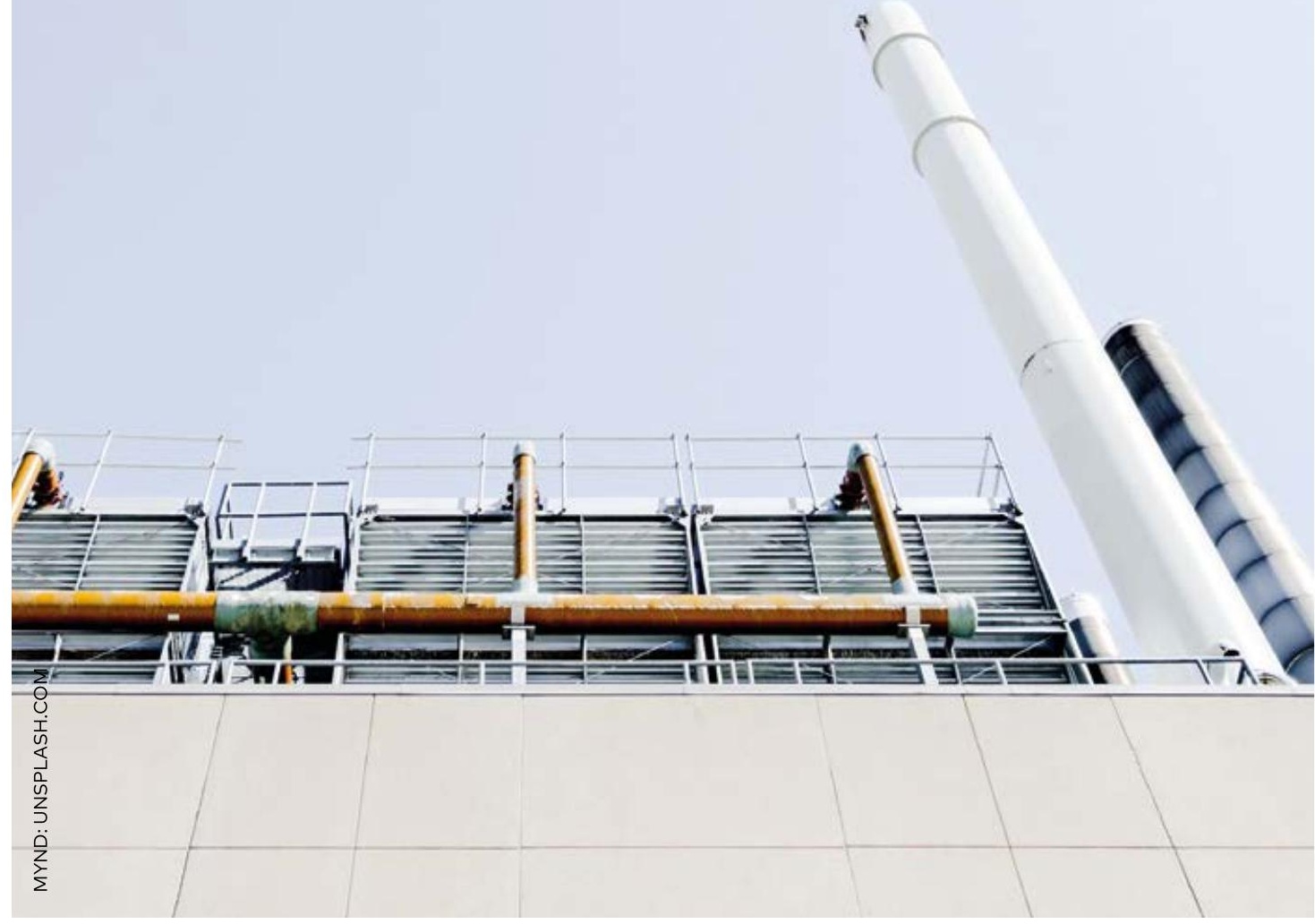




\section{Markmið og forgangsröðun}

Framtíðarsýn norræns samstarfs á sviði orkumála er:

Öflugt, aðlögunarhæft samstarf sem byggir á trausti og er til pess fallið að próa norræn orkukerfi i pá átt að tryggja sampættasta og snjallasta græna hagkerfi heims með lágri kolefnislosun, mikilli samkeppnishæfni og afhendingaröryggi.

Markmið samstarfsins eru:

Í samræmi við framtíðarsýnina á orkusamstarfið að stuðla að stöðugu og tryggu framboði á orku, skilvirkum orkumarkaði og sjálfbærum hagvexti og velmegun fyrir íbúa Norðurlanda. Einnig skal orkusamstarfið stuðla að pví að löndin nái metnaðarfullum markmiðum sínum í umhverfis- og loftslagsmálum. Undir pað fellur hnattræn kynning á styrkleikastöðum Norðurlanda í orkugeiranum með próun tæknilausna sem stuðla að pví að loftslagsmarkmiðunum verði náð.
Á tímabilinu 2018-2021 verða eftirtalin svið í brennidepli í samstarfinu:

- Frambróun hins norræna raforkumarkaðar

- Endurnýjanlegir orkugjafar

- Aukin orkunýtni

- Upplýsingaskipti og samrád um stefnu norrænu landanna í orkumálum

- Orkurannsóknir og nýsköpun á vettvangi Norrænna orkurannsókna

- Norðurlönd í Evrópu, p.m.t. framkvæma Orkubandalags ESB

- Grannsvæði Norðurlanda, einkum Eystrasaltsríkin

- Orkutengd samgöngusjónarmið

- Orkugeirinn á Álandseyjum, í Færeyjum og á Grænlandi

- Aðrar pverlægar áætlanir og verkefni og alpjóðlegt samstarf

Í næstu köflum er greint frá starfinu sem fram fer á ofannefndum sviðum. 


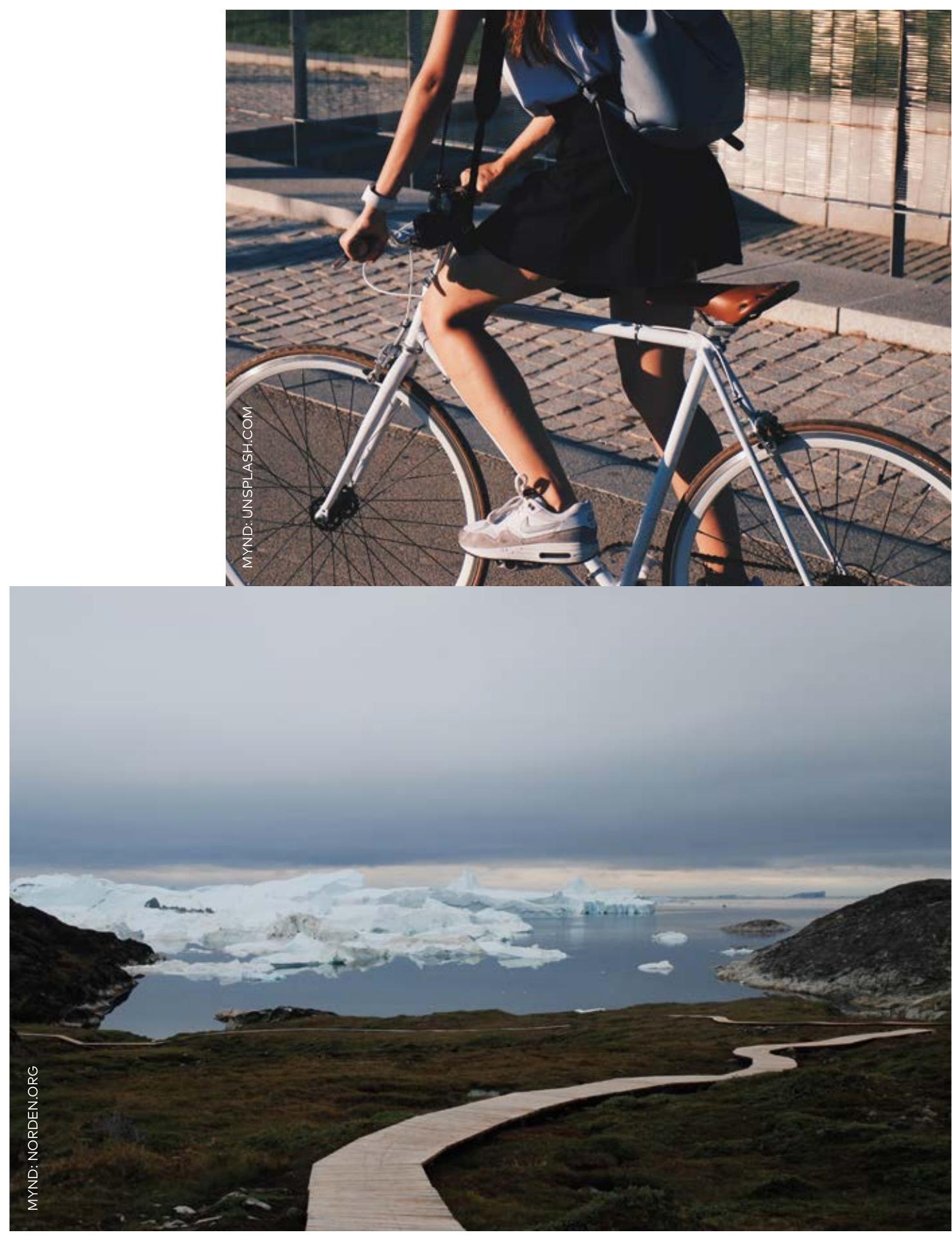




\section{Norrænn raforkumarkaður}

Saman mynda Noregur, Svípjód, Finnland og Danmörk samnorrænan raforkumarkað. Norræni heildsölumarkaðurinn fyrir raforku (Nordpool) hefur löngum verið alpjóðlega viðurkennd fyrirmynd í próun raforkumarkaða yfir landamæri. Norrænt samstarf um raforkumarkað er í stöðugri próun hvað varðar afhendingaröryggi, samkeppni og skilvirkni.

Með orkubandalagi ESB er m.a. óskað eftir pví að sameiginlegum evrópskum raforkumarkaði verði komið á fót. Stutt hefur verið við myndun slíks markaðar m.a. með nýjum markaðstengslum milli hlutamarkaða í Evrópu. pað landsvæði sem líta má á sem sameiginlegan raforkumarkað fer pví vaxandi og norrænn raforkumarkaður sampættist í síauknum mæli löndum og raforkumörkuðum á grannsvæðum Norðurlanda.

\section{FORGANGSMÁL}

Miklar breytingar eiga sér nú stað á evrópska raforkukerfinu. Petta stafar meðal annars af nýrri löggjöf $\mathrm{ESB}^{2}$ og próun í átt að dreifðari og sveiflukenndari endurnýjanlegri raforkuframleiðslu, auk virkari og sveigjanlegri notenda. Petta pýðir að samstarfinu um norrænan raforkumarkað mun enn vaxa fiskur um hrygg á næstu árum, einkum á eftirtöldum sviðum:

\section{Skilvirkni raforkumarkaðarins}

Efla parf dreifikerfið og nauðsynlegt getur reynst að gera breytingar á núverandi regluverki um raforkumarkaðinn til að sampætta sívaxandi hlut endurnýjanlegrar orku. Pörfin fyrir að efla dreifikerfið í löndunum veltur líka á pví hvernig uppbyggingu í nágrannalöndunum verður háttað. Aukinn hlutur sveiflukennds framboðs á raforku (vindorku, sólarorku o.fl.) setur nýjar kröfur m.a. hvað varðar jafnvægi og eykur pörf á stjórnun og eftirliti með dreifikerfinu. Petta örvar einnig próun snjalldreifikerfa fyrir raforku. Á sama hátt eykst pörfin fyrir geymslu á raforku pegar mikið er framleitt af henni til notkunar síðar pegar framleiðsla verður minni, eða pegar eftirspurnin eykst. Bættir möguleikar og hvatar fyrir neytendur til að bregðast við verðlagningu geta aukið sveigjanleika í raforkunotkun. Snjallir

\footnotetext{
${ }^{2}$ Pegar samstarfsáætlunin var sampykkt stóðu viðræður enn yfir um tillögurnar í Vetrarpakka framkvæmdastjórnarinnar. Pví er vísað til peirra hér sem „tillagnanna".
} 
eiginleikar dreifikerfa auðvelda dreifingu á eftirspurninni yfir tíma og draga úr tímabilum með hátt notkunarhlutfall raforku. Mikilvægt er að fylgjast með próuninni á pessum sviðum og hugsanlega móta sameiginlega stefnu par að lútandi. Í peirri hugmyndavinnu verður tekið mið af pví sem lagt var til í hinni stefnumótandi úttekt. Til að auka sveigjanleika og skilvirkni i raforkukerfinu mun fara fram rafvæðing á innviðum hitaveitu-, kæli- og samgöngukerfa, í áföngum og par sem við á.

\section{Skipulag tengslaneta og fjárfestingar}

Norrænn raforkumarkaður einkennist af skilvirkri auðlindanýtingu við framleiðsluna. Fækka ætti flöskuhálsum í norræna raforkudreifikerfinu, sem skapa mikinn og langvarandi mun á raforkuverði, upp að pví marki sem er pjóðhagslega hagkvæmt. Árið 2010 ákváðu norrænu orkumálarádherrarnir að aðeins ætti að ráðast í pjóðhagslega arðbærar fjárfestingar í dreifikerfum. Sé hagræði og kostnaði misskipt milli landanna eiga svæðisveiturekendur að ræða skiptingu kostnaðar og tekna. Mikilvægt er að flutningskerfisfyrirtæki starfi áfram og efli samstarfið um m.a. próun pjóðhagslega hagkvæmrar skipulagningar á raforkudreifikerfi og semji norrænar áætlanir fyrir próun slíkra kerfa.

\section{Ný ESB-löggjöf}

Áætlun framkvæmdastjórnar ESB frá 2016, Clean Energy for All Europeans (svonefndur "Vetrarpakki") (sjá bls. 25 fyrir ítarlegri umfjöllun um

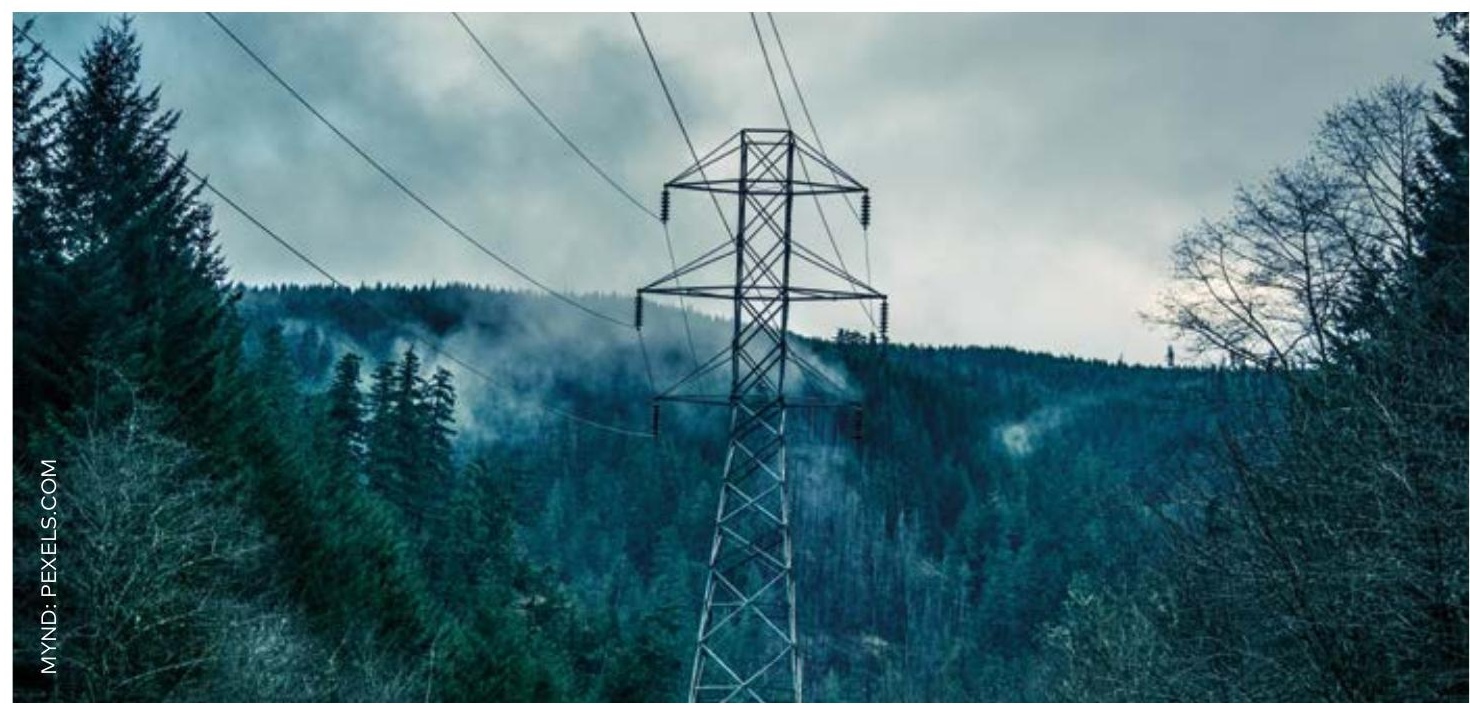




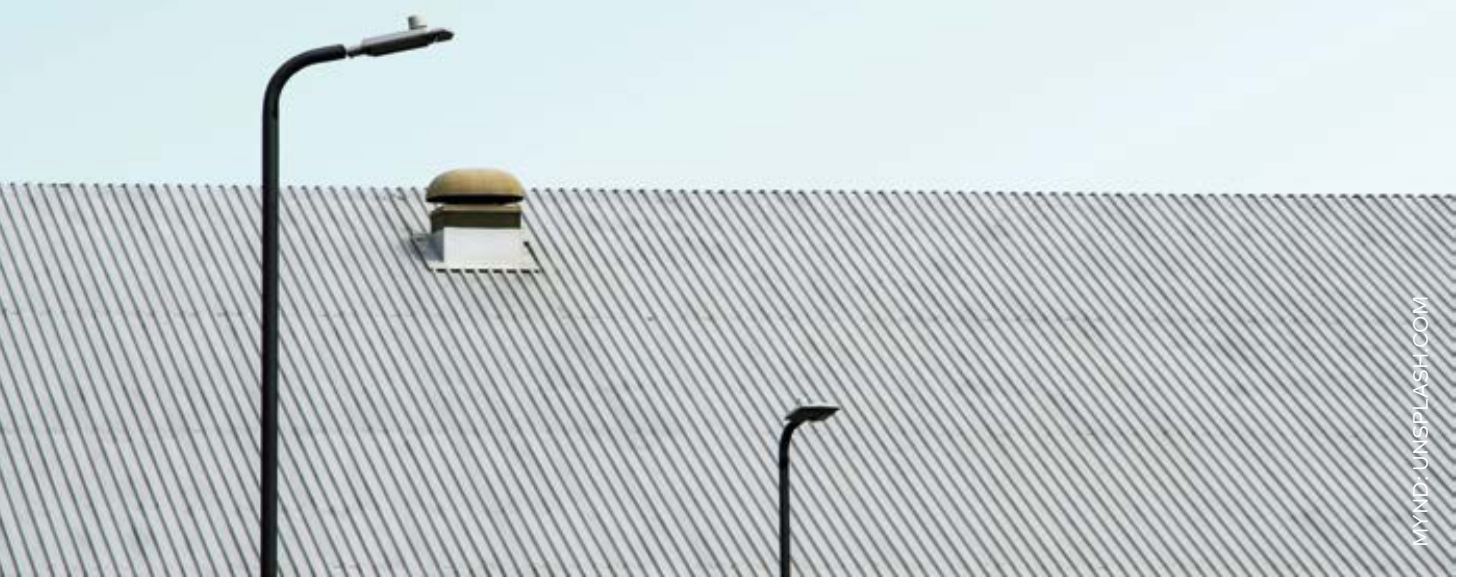


Norðurlönd í Evrópu) inniheldur m.a. tillögu að endurskoðaðri löggjöf um raforkumarkaðinn, p.e. endurskoðun á priðja pakkanum um innri markað ESB. Einnig kemur nýtt samkomulag um neyðarviðbúnað í stað tilskipunarinnar um afhendingaröryggi raforku. Mikilvægt er að gæta samnorrænna hagsmuna í viðræðum um hina nýju löggjöf og tryggja að ekki verði settar reglur sem standi hinum skilvirka norræna raforkumarkaði fyrir brifum. Einnig er mikilvægt að halda jafnvægi á milli pess sem hagkvæmt er að ákveða á vettvangi $E S B$, og pess sem æskilegra er að löndin ráði fram úr. Norrænn raforkumarkaður stendur framarlega á ýmsum sviðum miðað við aðildarlönd ESB. Pað býðir að norrænu löndin hafa mikið fram að færa til próunar sameiginlegs evrópsks raforkumarkaðar. pað verður mikilvægt forgangsmál í norrænu orkusamstarfi að tryggja pessa pætti. Á nýju gildistímabili áætlunarinnar verður pví haldið áfram, par sem við á, að próa og miðla samnorrænum sjónarmiðum til viðeigandi

aðila (t.d. framkvæmdastjórnar Evrópusambandsins, Evrópupingsins og aðildarlandanna).

Einkum er svæðisbundið samstarf í forgrunni i hinum ýmsu lagagerðum framkvæmdastjórnar ESB, samkvæmt tillögum í Vetrarpakka ársins 2016.
Tillögurnar eru nú til umfjöllunar og verður hrint í framkvæmd á gildistíma áætlunarinnar 2018-2021. Mikilvægt er að Norðurlönd, sem hafa mikla reynslu af svæðisbundnu samstarfi, leggi sitt af mörkum með pekkingu og ráðgjöf pegar að framkvæmd kemur.

\section{Samræmdari smásölumarkaður}

Samræmdari smásölumarkaður raforku með auknu valfrelsi fyrir neytendur og samkeppni milli birgja stuðlar að skilvirkni á raforkumarkaði. Árið 2009 ákváðu norrænu orkumálaráðherrarnir að ráðast í aukna samræmingu á norrænum neytendamarkaði fyrir raforku. Samstarfsstofnun norrænna eftirlitsaðila með raforkumarkaði (NordREG) hefur síðan lagt fram tillögur að leiðum til að auka samræmingu á smásölumarkaðinum. Áhersla er lögð á að fækka hindrunum í starfsemi orkufyrirtækja í nokkrum norrænum löndum samtímis með samræmingu regluverks og starfshátta.

\section{Samskipti við markaðsaðila}

Á gildistímabili áætlunarinnar verður samráð við aðila raforkumarkaðarins og fleiri mikilvægt sem fyrr til að tryggja öflugt norrænt samstarf á sviði orkumála. Sérstök áhersla verður lögð á nákvæma útfærslu pessara samskipta á gildistímabili áætlunarinnar. 


\section{Endurnýjanlegir orkugjafar}

Norrænu löndin hafa, hvert á sinn hátt, gott aðgengi að endurnýjanlegum orkuauðlindum og eru í fararbroddi á heimsvísu hvað snertir hlutfall endurnýjanlegra orkugjafa í orkunotkun. Hlutur endurnýjanlegrar orku í norrænu löndunum nemur 30-70\%, ${ }^{3}$ sem er talsvert hærra en meðaltal ESB-landa upp á $16,7 \%$.

Orkubandalagið hefur mikil áhrif á próun endurnýjanlegra orkugjafa í norrænu löndunum. Endurskoðun stendur nú yfir á mörgum tilskipunum varðandi endurnýjanlega orkugjafa fyrir tímabilið 2020-2030, sjá einnig bls. 22 og 25.

\section{FORGANGSMÁL}

\section{Samstarf um núgildandi og væntanlegar tilskipanir ESB}

Áhersla er lögð á norrænt samstarf um innleiðingu tilskipana um endurnýjanlega orkugjafa fyrir og eftir árið 2020.

Samnorrænir hagsmunir verða metnir í ljósi tilskipunar ESB um endurnýjanlega orkugjafa fram að 2030 og par sem við á verða samnorræn sjónarmið próuð og peim miðlað til viðeigandi stofnana.

\section{Styrkjakerfi fyrir endurnýjanlega orku}

Með metnaðarfullri landsbundinni stefnu hafa norrænu löndin tryggt sér einhvern hæsta hlut endurnýjanlegrar orku sem pekkist í evrópskum orkukerfum. petta hefur meðal annars orðið að veruleika fyrir tilstilli styrkjakerfa, par sem Svípjóð og Noregur hafa t.d. notast við sameiginlegt vottunarkerfi, Danmörk hefur efnt til útboða á m.a. aflandsvindorku og Finnland hefur notast við kerfi par sem aukagjald er lagt á raforkuverð.

Miðlun reynslu af styrkjakerfum fyrir endurnýjanlega orkugjafa verður lykilatriði hér eftir sem hingað til. Að auki verður áhersla lögð á hvernig stefna landa hefur áhrif á grannlöndin, t.d. á raforkumarkaði. Pá verður sjónum beint að markaðspróun og stefnumótun innan ESB.

\section{Líforka}

Lífmassi er mikilvægur í orkubúskap norrænu landanna samanborið við Evrópusambandslönd, ekki síst í Finnlandi, Svípjóð og Danmörku. Ísland nýtir ekki lífmassa í miklum mæli. Í Finnlandi, Svípjóð og Noregi 


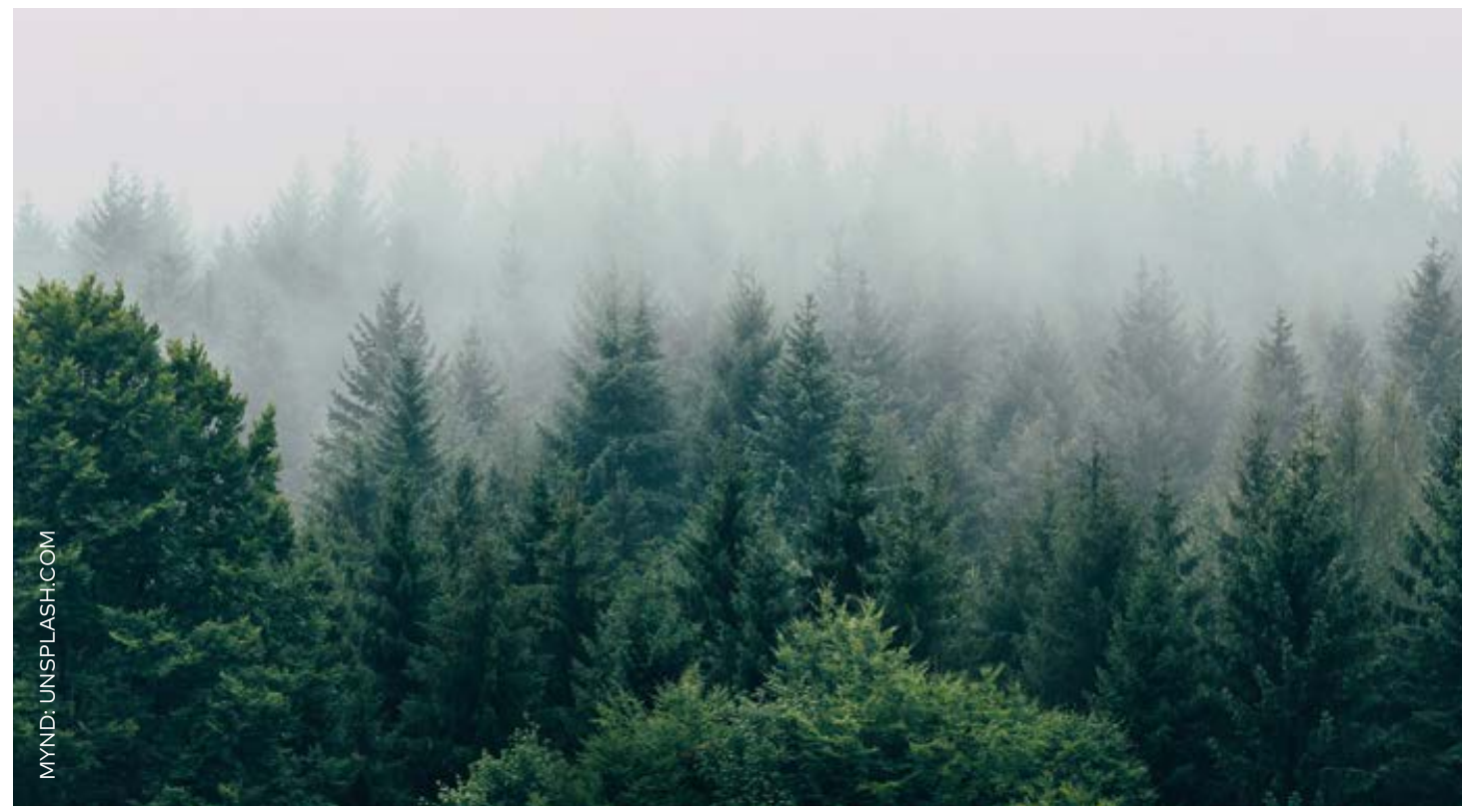

fæst lífmassaorka úr skógrækt og er

\section{Önnur viðfangsefni}

líforkugeirinn nátengdur skógvinnslu. Í Danmörku er að miklu leyti notaður innfluttur lífmassi. Eins og er (2015) er hlutur líforku af allri orkunotkun Norðurlanda næstum $20 \%$, en par af er lífmassi úr skógrækt 42\%. Dess er vænst að lífmassi gegni mikilvægu hlutverki á norrænum orkumörkuðum í framtíðinni.

I tilskipun ESB um endurnýjanlega orku (RED) er áhersla lögð á mikilvægi sjálfbærniviðmiða fyrir líforku. ${ }^{4}$ Áfram verður lögð áhersla á próunina innan ESB og almennt á próun líforku á Norðurlöndum.

Möguleikar á samstarfi um dreifða framleiðslu á endurnýjanlegri raforku verða kannaðir. Einkum verður áhersla lögð á mikilvægi pess að fleiri heimili verði "framneytendur" orku, p.e.a.s. bæði framleiðendur (t.d. með sólarsellum) og neytendur. Einnig mun fara fram mat á vægi pessa fyrir skilvirkan raforkumarkað. Um er að ræða mikilvæg tengsl fyrir ýmsa pætti norræns orkumálasamstarfs og verður mat lagt á pau.

\footnotetext{
${ }^{4}$ Pegar samstarfsáætlunin var sampykkt stóðu enn yfir viðræður um tillögu að tilskipun Evrópupingsins og Ráðsins um að stuðla að nýtingu á endurnýjanlegum orkulindum (endurskoðun á tilskipuninni um endurnýjanlegar orkulindir). Pegar vísað er til innihalds "nýrrar löggjafar ESB" er bví átt við tillögu framkvæmdastjórnarinnar.
} 


\section{Að̃ auka orkunýtni}

Orkunýtni er lykilatriði í sjálfbæru orkukerfi og stuðlar einnig að pví að efla sjálfbærni í umhverfismálum, efla samkeppnisstöðu og tryggja afhendingaröryggi. Orkunýtni er norræn styrkleikastaða sem öll löndin leggja mikið upp úr. Orkunýtni er mikilvæg í bygginga- og húsnæðisgeira, í iðnaði, samgöngugeira, vörupróun og framleiðslu og í orkuflutningum.

Norrænt samstarf á sviði orkunýtni stuðlar að aukinni pekkingu um og skilningi á stefnum landanna á sviðinu, t.d. með ráðstöfunum og verkefnum í pungaiðnaði sem stuðla að pví að sameiginlegum norrænum markmiðum verði náð. ESB gegnir einnig mikilvægu hlutverki á sviði orkunýtni gegnum sameiginleg markmið og reglur sem mynda ramma um starf landanna í málaflokknum. M.a. eru öll löndin aðilar að lagagerðum ESB/EES á sviði merkinga fyrir umhverfisvæna hönnun og orku.

\section{FORGANGSMÁL}

Miðlun reynslu af framkvæmd tilskipana ESB á sviði orkunýtni verður haldið áfram. Mikilvægt samstarfssvið verður endurskoðun sem framkvæmdastjórn ESB kynnti í Vetrarpakkanum, m.a. tillögur um endurskoðun á tilskipuninni um orkunýtni og tilskipuninni um orkuafköst bygginga. $^{5}$

Skipulag og inntak norræns samstarfs er síbreytilegt, en rammarnir hafa haldist nokkurnveginn óbreyttir. Samstarf um orkunýtni verður próað í átt að samstarfi í samstarfsnetum með megináherslu á upplýsingaskipti.

\section{Nordsyn}

Nordsyn er verkefni sem hefur skilað góðum árangri um markaðseftirlit með merkingum fyrir umhverfisvæna hönnun og orku. Merkingar fyrir umhverfisvæna hönnun og orku eru sprottnar úr löggjöf ESB, en markaðseftirliti með merkingunum er sinnt af löndunum. Framkvæmdastjórn ESB hvetur til samstarfs um markaðseftirlit, par sem slíkt sé forsenda pess að sömu leikreglur gildi um alla markaðsaðila. Petta hefur tekist að miklu leyti á Norðurlöndum, par sem komið hefur á daginn að með pví að sameina krafta okkar eigum við betri möguleika á að próa starfið enn frekar.

\footnotetext{
${ }^{5}$ Pegar samstarfsáætlunin var sampykkt stóðu viðræður enn yfir um tillögu framkvæmdastjórnarinnar að endurskoðun á tilskipun Evrópupingsins og Ráðsins 2012/27/EU um orkunýtni og tillögu framkvæmdastjórnarinnar að breytingum á tilskipun Evrópupingsins og Ráðsins 2010/31/EU um orkuafköst bygginga. Pegar vísað er til innihalds „nýrrar löggjafar ESB” er pví átt við tillögu framkvæmdastjórnarinnar.
} 
Markaðseftirlitsyfirvöld frá Danmörku, Íslandi, Finnlandi, Noregi og Svípjóð taka pátt í Nordsyn.

Til að byrja með byggði verkefnið á framtaksverkefni norrænu forsætisráðherranna um grænan hagvöxt, ${ }^{6}$ en hefur síðan próast yfir í verkefni með mörgum undirverkefnum, m.a. um túlkun á reglugerðum um vörur, rannsóknir á flóknum vörum, norrænar vörur sem hafa vægi i stefnumótun, úttekt á áhrifum markaðsstjórnunar og sameiginlegt upplýsingaverkefni á netinu. Um leið hefur Nordsyn-hópurinn orðið mikilvægur vettvangur fyrir pátttakendur til að ræða önnur mál sem tengjast reglum ESB og EES um merkingar fyrir umhverfisvæna hönnun og orku, m.a. almenn málefni er varða væntanlegar reglugerðir um vörur eða endurskoðun á gildandi reglugerðum. Ekki er alltaf unnt að ná samkomulagi um samnorræna afstöðu, en jafnvel í peim tilvikum sem pað tekst ekki er hægt að setja fram norræn sjónarmið á vöru sem hefur sérstaka býðingu á Norðurlöndum, eftir pví sem gagnast getur í viðræðum á vettvangi ESB.

\section{FORGANGSMÁL}

- Ný rammatilskipun um orkumerkingar fyrir vörur var sampykkt af ESB í júní 2017. Í pví sambandi verður m.a. komið á fót sameiginlegum gagnagrunni yfir allar orkumerktar vörur. Í tilskipuninni er einnig gerð krafa um aðgerðir í upplýsingamálum, sem gagnlegt er fyrir norrænu löndin að ráðast i í sameiningu.

- í tengslum við m.a. aðgerðir í upplýsingamálum verður sérstök áhersla lögð á hlutverk neytenda varðandi orkunýtni og græn umskipti. Einn liður í pví felst í mati á hlutverki neytenda í tengslum við notendasvörun á raforkumarkaði.

- Próun nýrra aðferða og prófana varðandi sameiginlega hagkvæma markaðsstjórnun.

- Áframhaldandi áhersla á stefnumarkandi norræna vöru á borð við varmadælur, en veðurfar á Norðurlöndum hefur áhrif á virkni peirra.

- Áframhaldandi áhersla á markaðsstjórnun flókinna vara.

"Verkefnið "Norðurlönd - leiðandi í grænum hagvexti" var forgangsverkefni Norrænu ráðherranefndarinnar sem norrænu forsætisráðherrarnir ýttu úr vör í nóvember 2011. 


\section{Upplýsingaskipti og samráð um stefnu norrænu landanna í orkumálum}

Vetrarpakki framkvæmdastjórnar

ESB innihélt tillögu að stjórnkerfi

fyrir orkubandalagið. I framkvæmd

mun tillagan hafa í för með sér nýja

samræmingu á skýrslugjöf og skipulagi

á öllum fimm sviðum orkubandalagsins

(raforkumarkaður, tryggt orkuframboð,

orkunýtni, afkolun (p.m.t. endurnýjanleg

orka og Carbon Capture and Storage

(CCS)) og rannsóknir og próun/

nýsköpun). Hin aukna áhersla

Vetrarpakkans á svæðisbundin málefni

er einkum áhugaverð fyrir norrænt

orkumálasamstarf.
Tillögurnar ${ }^{7}$ verða ræddar frekar á

gildistímabili áætlunarinnar. Meðal

annars verður rætt hvert hlutverk

norræns samstarfs um upplýsingaskipti

og samráð um stefnu landanna

í orkumálum getur verið. Í peirri

hugmyndavinnu verður tekið mið af pví sem lagt var til í hinni stefnumótandi úttekt.

\footnotetext{
${ }^{7}$ Pegar samstarfsáætlunin var sampykkt stóðu viðræður enn yfir um tillögurnar í Vetrarpakka framkvæmdastjórnarinnar. Pví er vísað til peirra hér sem "tillagnanna".
} 


\section{Orkurannsóknir}

Norrænar orkurannsóknir (NEF) eru vettvangur sameiginlegra orkurannsókna og -greininga á vegum Norrænu ráðherranefndarinnar. Norrænar orkurannsóknir eiga í nánu samstarfi við orkurannsóknastofnanir landanna.

Stefnumarkandi umboð fyrir starfsemi Norrænna orkurannsókna (NEF) á komandi tímabili (sbr. viðauka C) á að tryggja samfellu milli pessarar samstarfsáætlunar, norræns orkumálasamstarfs, sampykkta og fjárveitingarbréfa NEF, stefnu NEF fyrir tímabilið 2018-2021 auk útfærslu á fjárhagsáætlun Norrænu ráðherranefndarinnar. Hafa skal framkvæmd og niðurstöður hinnar stefnumótandi úttektar á sviði orkumála til hliðsjónar í starfi stofnunarinnar. Á heildina litið skal öll starfsemi NEF greiða fyrir norrænu orkumálasamstarfi, notagildi og kynningu á Norðurlöndum.

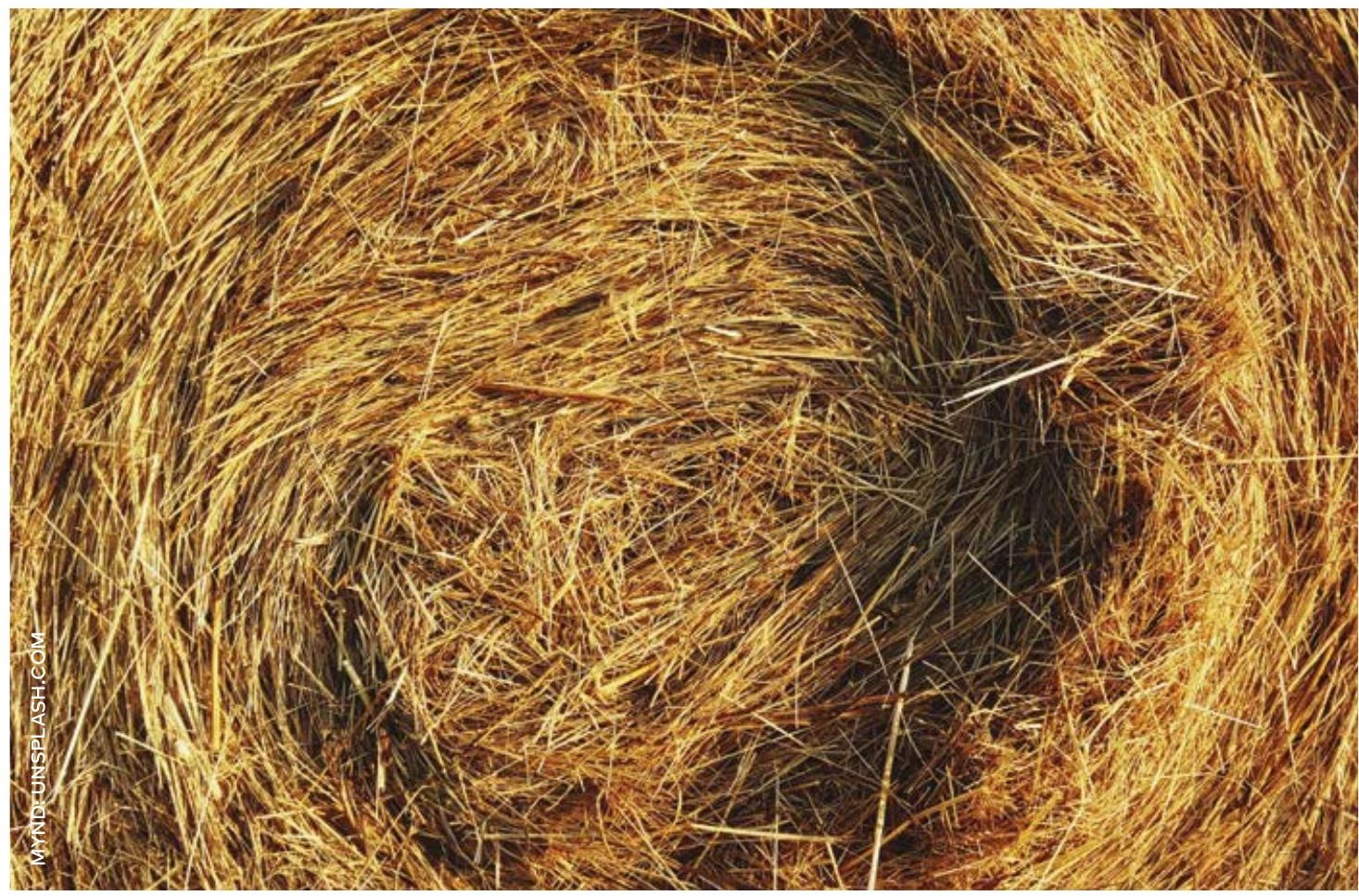



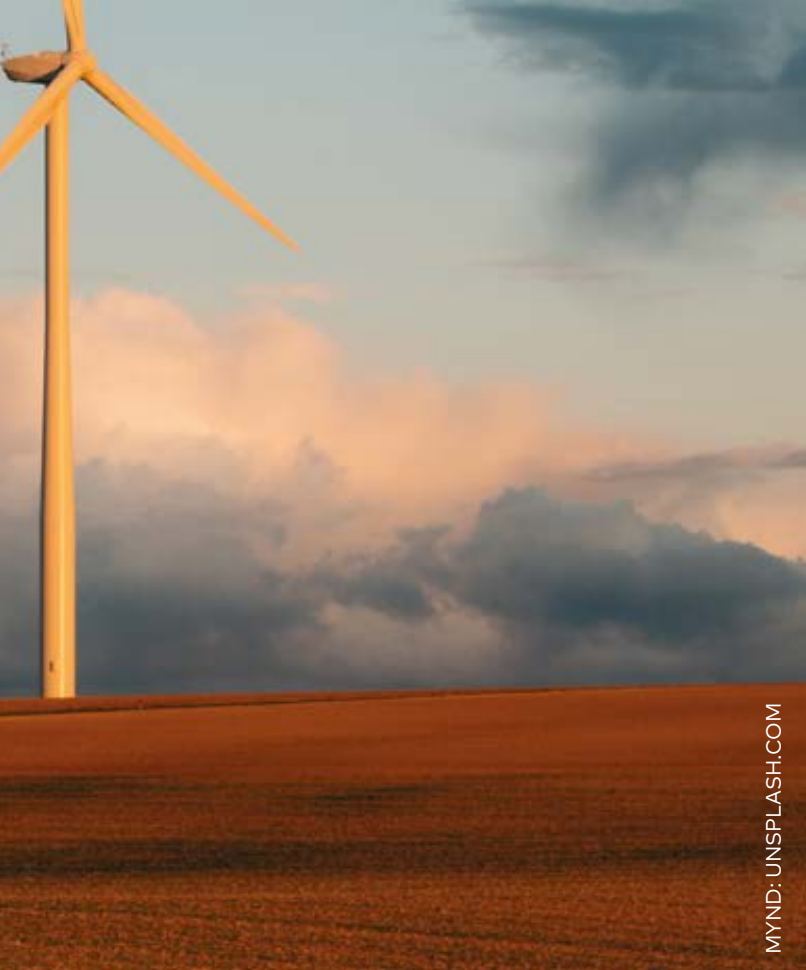


\section{Norðurlönd í Evrópu (ESB/EES) og annað̃ alpjóðlegt samstarf}

Málefni ESB/EES og önnur alpjóðleg málefni á sviði orkumála hafa verið á dagskrá í opinberu norrænu orkumálasamstarfi frá upphafi, nánast samhliða pví að norrænu löndin hafa valið að koma að Evrópusamstarfinu með ýmsum hætti, sum á vettvangi ESB (Finnland, Svípjóð og Danmörk) og sum innan EES/EFTA (Ísland og Noregur).

Orkumálasamstarfið hefur myndað margslunginn vef tvíhliða og marghliða verkefna í áranna rás. Á mörgum peirra sviða par sem norrænu löndin eiga sér fulltrúa er eðlilegt og hagkvæmt að efla norrænt samstarf og samræma sjónarmið landanna.

\section{Norðurlönd í Evrópu}

Talið er að framtíðarsýnin um evrópskt orkubandalag og tillögur par að lútandi, sem nú eru í ákvörðunarferli og á framkvæmdastigi, muni skipta miklu við mótun framtíðarstefnu landanna í orkumálum. Af pví leiðir að áhrifa af ferlum og aðgerðum ESB á sviði orkumála gætir í sívaxandi mæli á Norðurlöndum. Petta á við í öllum löndunum, hvort sem pau eiga aðild аð ESB eða ekki. Noregur og Ísland taka ekki beinan pátt í viðræðum um stefnu ESB í orkumálum, en verða pó fyrir áhrifum af nýjum lagagerðum gegnum EES-samninginn. Í norrænu samstarfi á sviði orkumála 2014-2017 var tekið tillit til stefnu og tilskipana sem miðuðu að árinu 2020, en í komandi orkumálasamstarfi parf að fylgja náið pví ákvarðana- og framkvæmdarferli sem hafið er innan ESB til undirbúnings á starfinu að nýjum markmiðum fyrir 2030. Norræn samstarfsáætlun á sviði orkumála fyrir tímabilið 2018-2021 fer pannig saman við lokahnykkinn í viðræðum um margvíslega löggjöf ESB og upphaf framkvæmdar peirra lagagerða sem m.a. flétta inn almenn markmið ESB fram til ársins 2030.

Starfi ESB að orkubandalaginu fylgir umtalsverð nútímavæðing og uppfærsla á reglugerðum sem miða að pví að ná loftslagsmarkmiðum ESB fram að 2030. Einkum gæti Vetrarpakkinn, sem inniheldur átta mismunandi lagagerðir, komið að gagni í norrænu orkumálasamstarfi.

Áfram verður hlúð að rótgrónum tengslum við Eystrasaltsríkin á komandi gildistímabili, m.a. á vettangi ESB. Einnig munu norrænu löndin bjóða Eystrasaltslöndunum á valda viðburði sem varða sameiginlega hagsmuni. Samstarfið við Eystrasaltsríkin hefur einkum farið fram á ráðstefnum, pá sérstaklega um viðfangsefni sem varða orkumálastefnu ESB.

Leitast verður við að próa áfram samstarfið við grannsvæði Norðurlanda, einkum við Eystrasaltsríkin prjú, á vettvangi verkefnisins Baltic Energy Market Interconnection Plan (BEMIP) og 
ýmissa óháðra norrænna verkefna. Pá verður eflt samstarf við Eystrasaltsríkin um orkutækni metið á grundvelli starfs NEF að Baltic Energy Technology Perspectives.

Framtíðarsýnin fyrir komandi gildistímabil er að nýta pann styrk sem felst í sameinaðri rödd Norðurlanda með virkum hætti, bæði á formlegum og óformlegum vettvangi. Petta á einkum við á vettvangi ESB/EES, en einnig annars staðar par sem norrænu löndin taka pátt, svo sem á Fimmhliða orkuvettvangi, vettvangi BEMIPverkefnisins, North Sea Countries Offshore Wind Initiative, Baakeverkefnisins o.s.frv. Einnig á vettvangi par sem til dæmis svæðisveiturekendur og óháð eftirlitsyfirvöld taka pátt íýmsu svæðisbundnu samstarfi.

\section{Annað alpjóðlegt samstarf}

Norrænu löndin taka einnig pátt í öðru, hnattrænna orkumálasamstarfi, svo sem á vettvangi Albjóðaorkumálastofnunarinnar (IEA) og International Renewable Energy Agency (IRENA). I albjóðlegu samhengi getur reynst afar gagnlegt fyrir Norðurlönd að samræma aðgerðir par sem sameiginlegir hagsmunir eru greinilega fyrir hendi, og par sem unnt er að skipuleggja sameiginlegar aðgerðir. Í skýrslu Albjóðaorkumálastofnunarinnar og Norrænna orkurannsókna (NEF), Nordic Energy Technology Perspectives
(NETP), kemur fram að Norðurlönd séu mjög framarlega í grænum umskiptum og hafi margvíslegar styrkleikastöður sem nýta megi á hnattræna vísu, bæði í tengslum við útflutning og til að efla samnorræn pólitísk sjónarmið.

Framtaksverkefni forsætisráðherranna fyrir árið 2017 um norrænar hnattrænar orkulausnir mun standa yfir á gildistíma áætlunarinnar og mynda forgangssvið. Í pví sambandi verður sömuleiðis lögð áhersla á samstarf við norrænt atvinnulíf um að próa og standa vörð um norrænar styrkleikastöður og útflutning.

Norrænt verkefni á fundi orkumálaráðherranna árið 2016 sem sneri að pví að fá hina alpjóðlegu fundi orkumálaráðherra, Clean Energy Ministerial/Mission Innovation (CEM9/ MI3), til Norðurlanda árið 2018, sýnir greinilega hvernig norrænt samstarf á sviði orkumála getur stutt við og próað alpjóðleg verkefni. Sömuleiðis getur sameiginlegt gestgjafahlutverk norrænu landanna nýst til að koma forgangsmálum peirra á dagskrá og vekja athygli á norrænum lausnum og tækni. Auk pess að Norðurlöndin gegni hlutverki gestgjafans á fleiri leiðtogafundum og ráðstefnum í framtíðinni mun náið norrænt samstarf tryggja að Norðurlöndin verði áfram mikilvægur aðili sem stuðlar að grænum umskiptum um heim allan. 


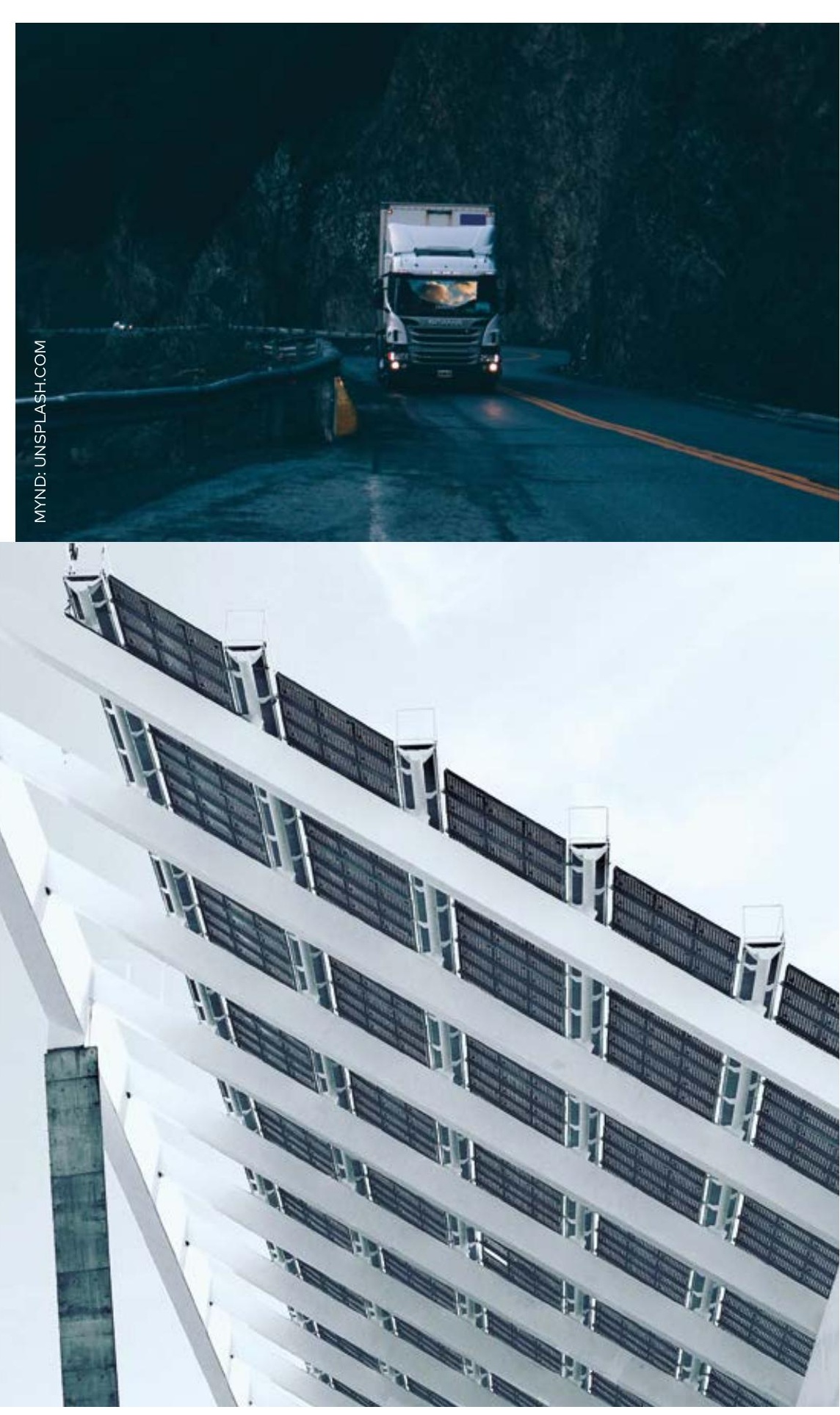




\section{Pverlæg pemu}

\section{Orkutengdir fletir á samgöngumálum}

Samgöngumál eru afar mikilvæg út frá almennum markmiðum landanna í loftslags- og orkumálum, ekki síst par sem notkun jarðefnaeldsneytis er mest í peim geira. Náið norrænt samstarf á sviðinu verður nauðsynlegt til að ná markmiðunum. Á komandi gildistímabili áætlunarinnar verður sett í forgang að pétta samstarfið.

Skilvirkt samgöngukerfi kallar á skilvirkar tæknilausnir og samstarf yfir landamæri. Slíkt samstarf verður einnig afar mikilvægt fyrir möguleika iðnaðarins til að próast og prófa nýjar lausnir. Tillaga hinnar stefnumótandi úttektar um sameiginlega sýn á samgöngumál og um að nota öll Norðurlönd sem prófunarvettvang fyrir nýja tækni verður höfð til hliðsjónar í starfinu að pví að efla norrænt orkumálasamstarf á sviði samgöngumála.

Samstarfið um samgöngumál er snúið sökum pess að um er að ræða pverlægt pema. Í pví felst áskorun fyrir löndin hvert fyrir sig, og ekki einfaldast málið í samstarfi peirra yfir landamæri. Í nánara samstarfi um samgöngumál á sviði orkumála verður áhersla pví fyrst um sinn lögð á pá hluta samgöngugeirans sem teljast hafa mesta tengingu við orkumálin. Pað á til dæmis við um rafvæðingu og notkun lífeldsneytis (og lífgass) í samgöngum í lofti, á láði og á legi. Áhersla verður lögð á sameiginleg hagsmunamál, svo sem hvað viðkemur stöðlun, innviðum, upplýsingaöflun, tækjum, viðskiptalíkönum og áhrifum á hinn samnorræna raforkumarkað.

Annað sem lagt gæti grundvöll að nánara orkumálasamstarfi á sviði samgöngumála er framkvæmd tillögu ESB að endurskoðun tilskipunar um að efla hlut orku frá endurnýjanlegum orkugjöfum, ${ }^{8}$ par sem samgöngugeirinn er innifalinn.

Eðlilegur útgangspunktur pess starfs gæti verið sú starfsemi sem pegar fer fram á vettvangi Norrænna orkurannsókna. Út frá tæknilegum tillögum á sviðinu er hægt að koma á nánara samstarfi/samhæfingu milli stefna landanna á sviðinu. Pannig má efla norrænar styrkleikastöður og mynda öflugri grundvöll fyrir pví að ná hinum metnaðarfullu markmiðum landanna í loftslagsmálum með skilvirkum hætti.

\footnotetext{
${ }^{8}$ Pegar samstarfsáætlunin var sampykkt stóðu viðræður enn yfir um tillögu að tilskipun Evrópupingsins og Ráðsins um bætta nýtingu á endurnýjanlegum orkulindum (endurskoðun á tilskipuninni um endarnýjanlegar orkulindir).
} 


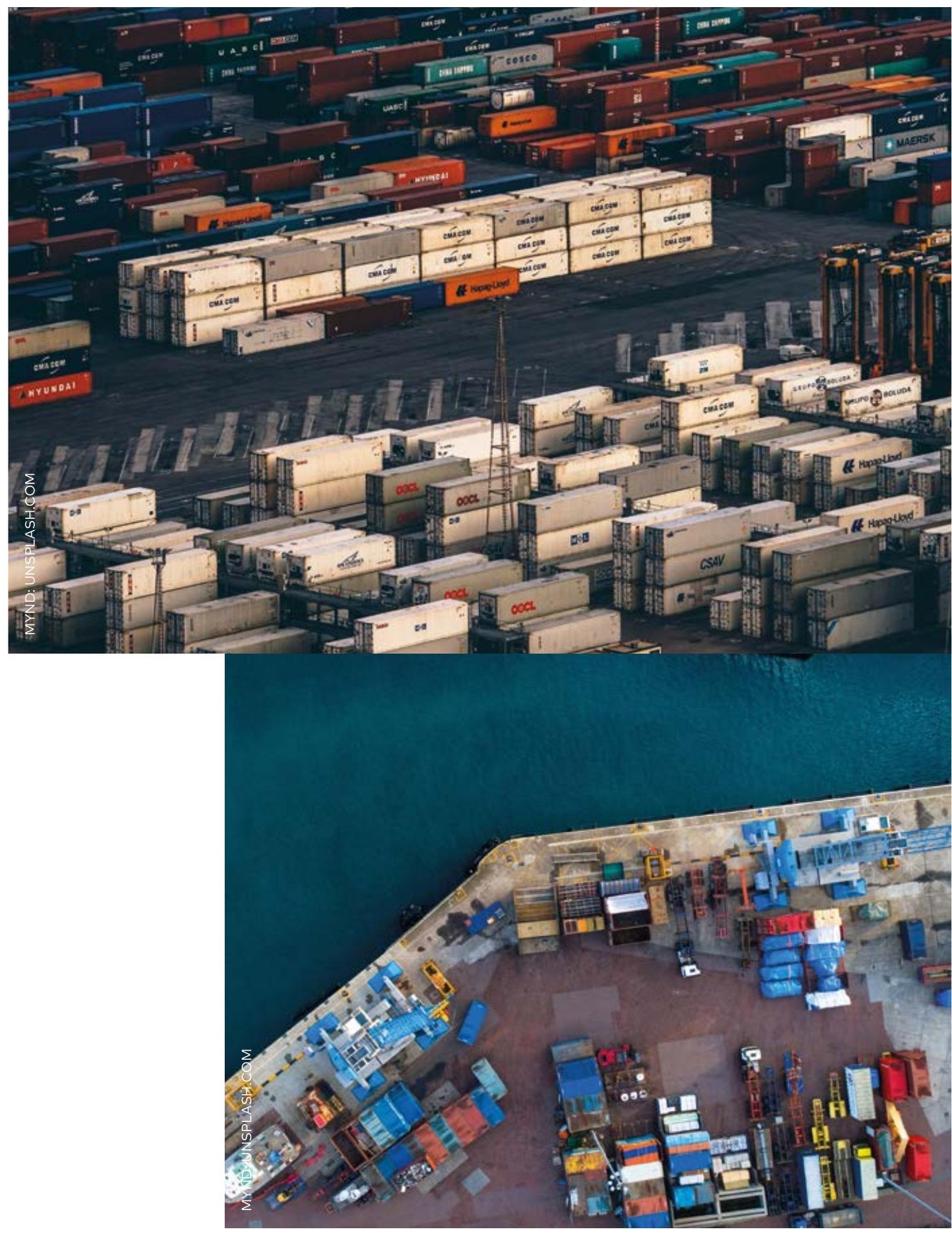


Sem liður í starfi orkugeirans að samgöngumálum er einnig stefnt að pví að festa í sessi nánara samstarf við aðra geira og aðila á sviði samgöngumála. Skipulag samstarfsins verður metið á tímabilinu.

\section{Norrænt orkumálasamstarf á Álandseyjum, í Færeyjum og á Grænlandi}

Undanfarin ár hefur Norræna ráðherranefndin lagt áherslu á að efla starf norrænu landanna að pví að tryggja aðgang að sjálfbærri og endurnýjanlegri orku. Petta á að sjálfsögðu einnig við Færeyjar og Grænland. Álandseyjar eru hluti hins sameiginlega norræna raforkumarkaðar og par er m.a. unnið að próun snjallkerfa fyrir raforku. Ennfremur verður áhersla lögð á bá möguleika sem fyrir hendi eru til að styðja við forgangsmál pessara svæða (samkvæmt stefnum og áætlunum) og skapa aukinn norrænan virðisauka með samlegðaráhrifum. Pannig á norrænt samstarf að koma til móts við hinar ýmsu áskoranir sem löndin, og allur heimurinn, standa frammi fyrir í orku- og umhverfismálum.

Framtíðarsýnin er að orkukerfi á svæðum sem liggja utan hins miðlæga orkukerfis Norðurlanda verði sampættur liður í norrænu orkumálasamstarfi. Á pessum svæðum ber að tryggja öruggt framboð á umhverfisvænni orku frá endurnýjanlegum orkugjöfum.

Framtíðarsýnin er að Norðurlönd verði leiðandi í hinum grænu umskiptum. Pessu á norrænt orkumálasamstarf að stuðla að með lausnamiðuðum aðgerðum, sérsniðnum að staðbundnum áskorunum, einnig hvað varðar svæði sem ekki eru tengd hinum samnorræna raforkumarkaði/raforkukerfi. Petta á að gera á grundvelli nýsköpunar, rannsókna, náms og reynslumiðlunar, auk framkvæmdar samstarfsverkefna. Nýta má svæði alls staðar á Norðurlöndum sem prófunarsvæði til að próa og prófa nýjar norrænar orkulausnir út frá styrkleikastöðum á hverjum stað. Pannig geta Norðurlönd eflt stöðu sína sem leiðandi svæði á sviði orkumála á heimsvísu. Petta starf er m.a. hægt að meta á grundvelli starfs NEF að orkumálum á Vestur-Norðurlöndum og norðurslóðum.

\section{Samhengi við pverlæg stefnumótunarskjöl}

Samstarfsáætlunin á sviði orkumála stuðlar að framtíðarsýn samstarfsráðherranna um nýskapandi, landamæralaus, sýnileg og opin Norðurlönd. Par sem við á stuðlar framkvæmd samstarfsáætlunarinnar einnig að framkvæmd priggja pverlægra stefna Norrænu ráðherranefndarinnar 
um sjálfbæra próun, málefni barna og ungmenna og jafnréttismál auk annarra pverlægra stefna í norrænu samstarfi. Önnur pverfagleg mál verða tekin fyrir á viðeigandi sviðum og af öðrum aðilum eftir bví sem telst viðeigandi.

Auk pess stuðlar sviðið með virkum hætti að pví í starfi Norrænu ráðherranefndarinnar að takist að uppfylla hin 17 heimsmarkmið SP um sjálfbæra próun (sjálfbærnimarkmiðin), enda er gert ráð fyrir að markmiðin muni gegna mikilvægu hlutverki fyrir Norðurlönd í nánustu framtíð. Markmiðin eru misjafnlega mikilvæg fyrir sviðið. Eftirfarandi markmið gegna sérstöku hlutverki fyrir svið orkumála á gildistíma áætlunarinnar:
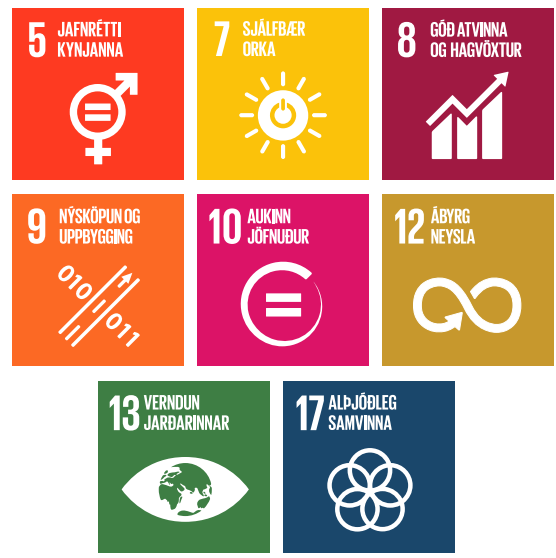


\section{Viðauki A}

\section{Skipulag sviðsins}

Í pessum kafla er greint frá skipulagi sviðsins. Í janúar 2018 koma fulltrúar í norrænu samstarfi á sviði orkumála úr ráðherranefndinni um sjálfbæran hagvöxt (MRVækst), embættismannanefndinni um orkumál (EK-E), Norrænum orkurannsóknum (NEF) og starfshópum um samstarf á raforkumarkaði (EMG) og endurnýjanlega orku (AGFE), auk samstarfshópsins um orkunýtni (NGEE) og starfshóps yfirvalda um Nordsyn (MANO).

Frá upphafi pessa gildistímabils áætlunarinnar hefur Nordsyn verið fest í sessi sem starfshópur yfirvalda undir embættismannanefndinni um orkumál (EK-E), sem skipaður er fulltrúum eftirlitsyfirvalda.

Á gildistíma nýju áætlunarinnar verður áhersla lögð á að byggja upp samstarfið, einkum milli starfshópanna um raforkumarkað og endurnýjanlega orku.

MR-Vekst

EK-E

Starfshópar

AGFE

EMG

Starfshópur yfirvalda:

MANO

NEF

Samstarfshópur:

NGEE 


\section{Viðauki B}

\section{Stefnumótandi úttekt á sviði orkumála}

Í janúar 2016 fól Norræna ráðherranefndin Jorma Ollila, fyrrum forstjóra Nokia, að vinna stefnumótandi úttekt á pví hvernig próa mætti norrænt samstarf á sviði orkumála á næstu 5-10 árum. Í júní 2017 kynnti Olilla skýrsluna fyrir olíu- og orkumálarádherra Noregs og formanni norrænu ráðherranefndarinnar um atvinnu-, orku og byggðastefnu, Terje Søviknes, og framkvæmdastjóra Norrænu ráðherranefndarinnar, Dagfinn Høybråten. Skýrslan er innlegg í umræðuna um framtíðarsamstarf á sviði orkumála.

Hin stefnumótandi úttekt á orkumálasamstarfinu er liður í umbótaferli Norrænu ráðherranefndarinnar, en umbæturnar miða m.a. að pví að auka skilvirkni í starfi rádherranefndarinnar. Innblásturinn að hinum stefnumótandi úttektum er sóttur í hina svonefndu Stoltenberg-skýrslu á sviði varnar- og öryggismála.
Skýrsla Jorma Ollila, „Norrænt orkumálasamstarf: Öflugt í dag - enn öflugra á morgun", inniheldur 14 tillögur að nánara orkumálasamstarfi. Í skýrslunni er sjónum beint að umskiptum til grænnar orku, Parísarsamkomulaginu, próun á sviði orkumála innan ESB og stefnum norrænu landanna í orkumálum.

Skýrslan hefur verið mikilvægt innlegg í umræður um pessa samstarfsáætlun. Margar tillagnanna í skýrslunni hafa verið til hliðsjónar við gerð áætlunarinnar, einkum hvað snertir framtíðarsýn orkumálasamstarfsins og samstarfsins um orkurannsóknir, en einnig í tengslum við samstarf um orkumálaáætlanir landanna.

Tillögurnar í skýrslunni eiga við líðandi stund en einnig komandi ár og verða pví metnar reglulega með hliðsjón af framtíðarsýn fyrir orkumálasamstarfið, ekki síst svo að pjóni metnaðarfullum markmiðum landanna í loftslags- og orkumálum. 


\section{Viðauki C \\ Stefnumarkandi umboð fyrir Norrænar orkurannsóknir}

Stefnumarkandi umboð fyrir starfsemi

Norrænna orkurannsókna (NEF) á komandi tímabili á að tryggja samfellu milli pessarar samstarfsáætlunar, sampykkta og fjárveitingarbréfa NEF, stefnu NEF fyrir tímabilið 2018-2021 og útfærslu á fjárhagsáætlun Norrænu ráðherranefndarinnar. Hafa skal framkvæmd og niðurstöður hinnar stefnumótandi úttektar á sviði orkumála til hliðsjónar í starfi stofnunarinnar. Á heildina litið skal öll starfsemi NEF greiða fyrir norrænu orkumálasamstarfi, notagildi og kynningu á Norðurlöndum.

Meginmarkmið norræna samstarfsins á sviði orkumála er að stuðla að stöðugu og öruggu framboði á orku, sjálfbærum hagvexti og velmegun fyrir borgarana og pví að markmiðum í loftslags- og umhverfismálum verði náð. Samstarfið er einnig tæki til markaðssetningar á styrkleikastöðum Norðurlanda í orkugeiranum innan Evrópu og alpjóðlega.

Meginmarkmið NEF er að stunda orkurannsóknir sem styðja við norrænt orkumálasamstarf. Samkvæmt sampykktum NEF skal stofnunin standa vörð um og próa styrkleikastöður Norðurlanda á sviði próunar og stuðla að notkun samkeppnishæfra og sjálfbærra orkulausna. Petta er haft að undirstöðu pegar NEF ræðst í ný verkefni, t.d. rannsóknaverkefni. Jafnframt skal leggja áherslu á ríkt norrænt notagildi, einnig í evrópsku og alpjóðlegu samhengi. Pannig á NEF að stuðla að pví að ljá Norðurlöndum faglega rödd um orkumál í norrænu samstarfi um orkurannsóknir og -greiningu. Pað verður að veruleika með pví að fjármagna og greiða fyrir orkurannsóknum, samstarfsverkefnum, vinna valmöguleika og greiningar á sviði orkumála og kynna norrænt orkusamstarf.

NEF skilgreinir starfsemi sína innan ramma áætlana sem gilda til fjögurra ára. Áherslur NEF fyrir pessar áætlanir eru meðal annars skilgreindar á grunni hinnar norrænu samstarfsáætlunar á sviði orkumála. Í stefnumótandi áherslum fyrir tímabilið 2018-2021 segir að framtíðarsýnin felist í að veita faglegan grundvöll fyrir Norðurlönd til að verða leiðandi á heimsvísu í snjöllum orkulausnum. Pessu á að ná fram á vettvangi norræns samstarfs. Í rannsóknasamstarfinu verður sérstök áhersla lögð á græn umskipti á sviði raforku, hitaveitu og samgöngumála, svæðisbundin raforkunet, virka neytendur og rannsóknir á norrænum orkukerfum.

Starfsemi NEF er fjármögnuð af Norrænu ráoherranefndinni og fjárveitingum aðildarlandanna, en við pað bætast styrkir frá samstarfsaðilum úr opinberum geira eða einkageira. 


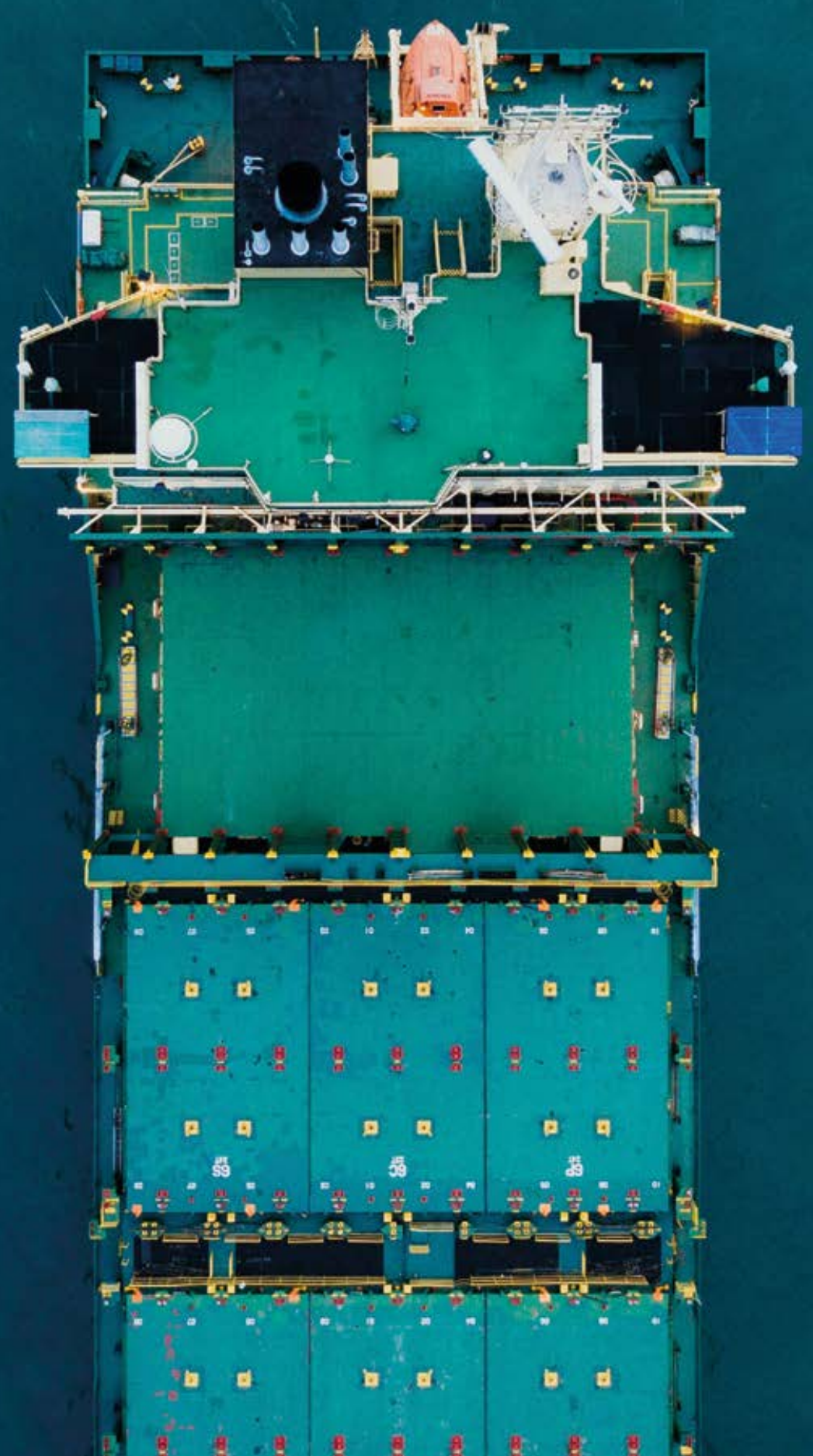




\section{$\mathbb{1}$}

Norræna ráôherranefndin

Nordens Hus

Ved Stranden 18

DK-1061 Copenhagen K

www.norden.org

Norrænu orkumálaráôherrarnir kynna hér með̃ nýja norræna samstarfsáætlun á sviði orkumála fyrir tímabilið 2018-2021.

Framtiỡarsýnin fyrir norrænt orkumálasamstarf felur í sér öflugt, að̋lögunarhæft samstarf sem byggir á trausti og og er til pess fallið að̃ próa norræn orkukerfi í pá átt aô tryggja sampættasta og snjallasta græna hagkerfi heims með lágri kolefnislosun, mikilli samkeppnishæfni og afhendingaröryggi.

Á tímabilinu 2018-2021 verð̆a eftirtalin svið í brennidepli í samstarfinu:

- Frampróun hins norræna raforkumarkað̃ar

- Endurnýjanlegir orkugjafar

- Aukin orkunýtni

- Upplýsingaskipti og samráô um stefnu norrænu landanna í orkumálum

- Orkurannsóknir og nýsköpun á vettvangi Norrænna orkurannsókna

- Norơurlönd í Evrópu, p.m.t. framkvæmd Orkubandalags ESB

- Grannsvæði Norơurlanda, einkum Eystrasaltsríkin

- Orkutengd samgöngusjónarmið̌

- Orkugeirinn á Álandseyjum, í Færeyjum og á Grænlandi

- Aőrar pverlægar áætlanir og verkefni og alpjóólegt samstarf 